\title{
The Silence of non-Western International Relations Theory as a Camouflage Strategy: The Trauma of Qing China and the Late Ottoman Empire
}

\author{
Hayriye Asena Demirer \\ İstanbul Gelişim University
}

\begin{abstract}
My main argument in this article is that there have been at least three important barriers to the development of non-Western international relations theory (NWIRT): intellectual barriers (traumatizing effects of the imposition of the "standard of civilization"); ideational barriers (dominance of Western concepts and contexts); and scientific barriers (imposition of the standard of science). I argue that the silence of NWIRT is substantially a side effect of the strategy of mimicking the West, which was developed as an intellectual defense mechanism or as a camouflage strategy for the (re)establishment and the survival of nonWestern states after their traumatic encounter with the Western states. Therefore, the surfacing of NWIRT discussions in the last decades can be attributed primarily to the maturation of an internal condition that is the revival of self-confidence in the residuals of former empires due to their regaining of rising power status and, thus, can be seen as a new phase of the 'revolt against the West.' On the other hand, I argue that the rise of NWIRT discussions are also related to the ripening of an external condition: some European schools of IR have been attempting to intellectually balance against the hegemony of American mainstream IRT, therefore, publication of edited books and special issues on NWIRT can also be read as searching for intellectual alliance with NWIRT.
\end{abstract}

Keywords: Non-western IR theory, standard of civilization, mimicking as a response to trauma, late Ottoman Empire, Qing China

\section{Introduction}

In the international relations (IR) literature, some scholars have criticized the dominance of the United States" in IR theory (IRT) and have, since the 1970s, defined it as "an American social science," a "not so international discipline"3 or "a hegemonic discipline". ${ }^{4}$ Later the scope of criticism was expanded to include European dominance ${ }^{5}$ in IRT, which turned

Hayriye Asena Demirer, Assistant Professor, İstanbul Gelişim University. Email: asenademirer@gmail.com. (D) 0000-00026679-1015.

Stanley Hoffman, “An American Social Science: International Relations," Daedalus 106, no. 3 (1977): 41-60; Miles Kahler, "International Relations: Still an American Science?," in Ideas and Ideals: Essays on Politics in Honor of Stanley Hoffmann, eds. L. Miller and M.H. Smith (Boulder, CO: Westview, 1993), 395-414; Ole Wæver, "The Sociology of not so International Discipline: American and European Developments in International Relations," International Organization 52, no. 4 (1998): 687-727; Steve Smith, "The United States and the Discipline of International Relations: 'Hegemonic Country, Hegemonic Discipline'," International Studies Review 4, no. 2 (2002): 67-85.

2 Hoffman, "An American Social Science".

3 Wæver, "The Sociology of not so International Discipline".

4 Smith, "The United States and the Discipline of International Relations".

5 Amitav Acharya and Barry Buzan, "Why is There No Non-Western International Relations Theory? An Introduction," 
the discussion into Western vs. NWIRT, defining Western-centrism as "epistemological imperialism" and Western IR as "nothing but a sophisticated ideology...that serve[s] to justify Western global hegemony". 7 Nearly all scholars publishing articles on the absence of NWIRT $^{8}$ or non-Western formal IRT $^{9}$ have explained this situation through the structure of systemic relations (the dominance of Western IRT) and local conditions.

In this article after a brief literature review section, I focus on three important barriers to the development of NWIRT: intellectual barriers (traumatizing effects of the imposition of the "standard of civilization"); ideational barriers (dominance of Western concepts and contexts); and scientific barriers (imposition of the standard of science), each of which will be discussed separately. I argue that these barriers have been established, on the one hand, at the intersection of formal and "informal colonization" 10 practices and the power-knowledge strategies of the West and, on the other hand, through cooperation among the West and Westernist elites to construct the basic institutions of modernity including the nation-state, science, secularism, as well as the "ideational structures" of IRT as universally acceptable ideal forms. However, I underline that one of the most important motivations behind the imitation of Western models is institutional camouflage for the (re)establishment and the survival of non-Western states after traumatic encounters with the Western states. Therefore I diagnose the silence of NWIRT as substantially a side effect of the strategy of mimicking ${ }^{11}$ the West that was developed as an intellectual defense mechanism or as a camouflage strategy in response to traumatic encounters with the West, and resulting from both a feeling of 'running behind' and an internalization of the linear progressive paradigm in history and thus a fear of engulfment by the great powers.

To show the traumatic effects of encounters with the West, I chose as case studies the experiences of Qing China and the late Ottoman Empire, since these two demonstrate that even the intellectuals of empires not formally colonized by the West have been deeply traumatized by this experience of informal colonization. One thing, I suppose, that has multiplied the effects of trauma of these Empires was their self-identification of superiority and their perception of imperial exceptionalism, a phenomenon that one could compare today with that of U.S. self-perception. This is very much the case with respect to China, since

International Relations of the Asia Pacific 7, no. 3 (2007): 287-312; Amitav Acharya and Barry Buzan, Non-Western International Relations Theory: Perspectives on and Beyond Asia (New York: Routledge, 2010); Navnita Chadha Behera, "Re-imagining IR in India," International Relations of the Asia Pacific 7, no. 3 (2007): 341-68; Arlene Tickner and Ole Wæver, eds., International Relations Scholarship around the World (Abingdon: Routledge, 2009); Ching-Chang Chen, "The Absence of Non-Western IR theory in Asia Reconsidered," International Relations of the Asia Pacific 11, no. 1 (2011): 1-23.

6 Deepshikha Shahi and Gennaro Ascione, "Rethinking the Absence of post-Western International Relations Theory in India: 'Advaitic Monism' as an Alternative Epistemological Resource," European Journal of International Relations 22, no. 2 (2016): 313-34.

Andrei P. Tsygankov and Pavel A. Tsygankov, "A Sociology of Dependence in International Relations Theory: A Case of Russian Liberal IR,” International Political Sociology 1, no. 4 (2007): 308.

Qin Yaqing, "Why is there no Chinese International Relations Theory?," International Relations of the Asia Pacific 7, no. 2 (2007): 313-40; Behera, "Re-imagining IR in India"; Tsygankov and Tsygankov, "A Sociology of Dependence in International Relations Theory"; Ersel Aydınlı and Julie Mathews, "Periphery Theorising for a Truly Internationalized Discipline: Spinning IR Theory out of Anatolia," Review of International Studies 34 (2008): 693-712.

9 Muthiah Alagappa, "International Relations Studies in Asia: Distinctive Trajectories," International Relations of the Asia Pacific 11, no. 2 (2011): 193-230; Takashi Inoguchi, "Are there any Theories of International Relations Theories in Japan," International Relations of the Asia Pacific 7, no. 3 (2007): 369-90.

10 Jesse Dillon Savage, "The Stability and Breakdown of Empire: European Informal Empire in China, Ottoman Empire and Egypt," European Journal of International Relations 17, no. 2 (2010): 161-85.

11 Although Homi Bhabha uses mimicry generally to explain the colonized non-white peoples' relations with the Western colonizer (Homi Bahabha, The Location of Culture (Routledge, 1994)), I argue that informally colonized states that are the inheritors of former empires (such as the Peoples Republic of China and the Republic of Turkey as well as the Russian Federation and the Islamic Republic of Iran) should be handled differently from the formal colonies, as I discuss below. 
they chose for much of their history to resist interaction with Western powers, ${ }^{12}$ and thus their eventual encounter with those Western powers has been particularly traumatic. For the Ottoman Empire I assume one of the most important factors that intensified the effects of trauma was their status deprivation from being an empire that was "knocking on the doors of Vienna" to becoming "the sick man of Europe" in relation to Western states.

Of course one can reasonably ask, given the considerable time gap between the development of IR as a discipline and these empires' traumatic encounters with the West, how could one attempt to explain the silence of NWIRT with the effects of this trauma? I want to draw attention to the idea that historical traumas were experienced collectively by the societies and that their effects are long term since they were transferred to "descendants who did not personally experience the rupture of traumatic events" through intergenerational transmission mechanisms. ${ }^{13}$ Certain new developments can also contribute to the revival of these collective traumas on a small scale. For instance, after the flux of Turkish labor to the Federal Republic of Germany following the signing of the temporary labor recruitment agreement in October 1961, historical narratives of barbarism and civilization as well as those of the so-called Islamic "Orient" and its place in Europe ${ }^{14}$ were revived, as were the effects of the trauma. Therefore, despite the considerable time gap, the effects of the traumas of Qing China and the Ottoman Empire have lasted, as evidenced by China's official description of their early encounter with western powers still as 'a century of humiliation,' and the definition of those Western powers in the Turkish national anthem as 'a monster with one tooth'.

In fact, I argue, the European great powers experienced a similar status of deprivation in relation to the U.S. due to the power transition from the European states to the U.S. after the two World Wars. In this case however, the cracks of intra-civilizational rivalry and conflict of interest between them were to a large extent papered over during the Cold War due to the Soviet threat, which brought them together under the same security roof. However after the Cold War, especially due to the U.S.' unilateral policies following the September 11 attacks, Christopher Layne argues that West Europeans started to perceive "U.S. hegemony as a greater threat than U.S. preponderance during the Cold War". ${ }^{15} \mathrm{He}$ defines "leash-slipping" as a new form of counterbalancing, in which states try to maximize their ability to conduct an independent foreign policy in relation to a hegemonic state, rather than fear being attacked by it. He further argues that European great powers have employed three leash-slipping counter balancing moves against U.S. hegemony: Britain's attempt to create a "third force," between 1945-48; French counterbalancing under De Gaulle; and the European Union's Security and Defense Policy. ${ }^{16}$ Along that same line, I would point out that some critical European schools, such as the English School, Critical theory (German), and Structural theory and Postmodernism (French) were attempts to intellectually balance against the American hegemony over IRT. Similar to external and internal balancing within

12 Arjun Appadurai, Modernity at Large: Cultural Dimensions of Globalization (Minneapolis: University of Minnesota Press, 1996), 27.

13 Carol A. Kidron, "Surviving a Distant Past: A Case Study of the Cultural Construction of Trauma Descendant Identity," Ethos 3, no. 4 (2004): 516.

${ }^{14}$ Leslie A. Adelson, "Touching Tales of Turks, Germans, and Jews: Cultural Alterity, Historical Narrative, and Literary Riddles for the 1990s," New German Critique 80, Special Issue on the Holocaust, (2000): 96-8.

${ }^{15}$ Christopher Layne, "The Unipolar Illusion Revisited: The Coming End of the United States' Unipolar Moment," International Security 31, no. 2 (2006): 23.

${ }^{16}$ Layne, "The Unipolar Illusion Revisited," 9-10, 30-6. 
hard balance of power, intellectual balancing, I argue, as a kind of soft balancing can be done either personally (internally) or externally (in an alliance with other countries' intellectuals) against the intellectual block of the other side. Therefore, I state that edited books or special issues on the absence of NWIRT not only promote the rise of NWIRT but also reflect the search for intellectual alliances through NWIRT, in particular Asian, and above all Chinese, to intellectually balance against the American hegemony.

In the conclusion section, I attribute the surfacing of NWIRT discussions in recent decades to, on the one hand, the promotion of NWIRT by some European schools of IR as an attempt to intellectually balance against the hegemony of American mainstream in an intellectual alliance with NWIRT, and on the other hand, to the revival of self confidence in the residuals of former empires.

This self confidence, I maintain, is reflected first in the fifth phase of "the revolt against the West, ${ }^{17}$ which Hedley Bull called a struggle for "cultural liberation" to "throw off intellectual or cultural ascendancy of the Western world so as to assert their own identity and autonomy in matters of the spirit". ${ }^{18}$ Bull went on to say that although "the revolt against Western dominance in relation to the four earlier themes has been conducted, at least ostensibly in the names of ideas or values that are themselves Western" the reassertion by Asian, African, and other non-Western peoples of their traditional and indigenous cultures has changed the nature of the revolt against the West:

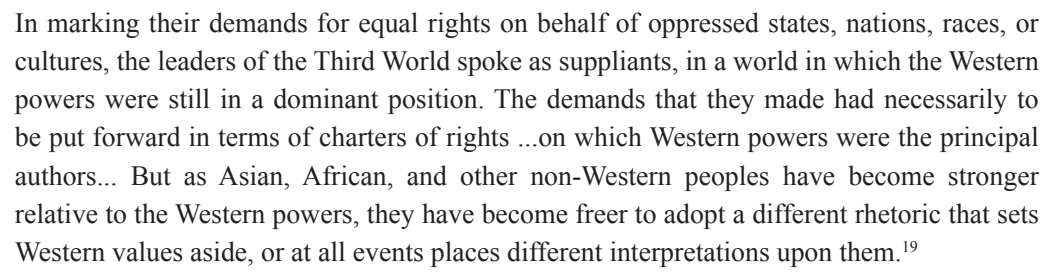

As a conclusion, however, I maintain that in searching for a non-hegemonic or a less hegemonic discipline we do not have to make a choice between universal vs. exceptionalist or systemic vs. subsystemic IRT, instead we can attempt to bring the systemic, the semisystemic and the sub-systemic elements together.

\section{Discussions on the Absence of NWIRT in IR Literature}

Qin Yaqing, despite the long intellectual tradition of the discipline of IR in China and its attraction, finds the nonexistence of a major IRT construction in China puzzling, and presents three factors to help explain this puzzle: the dominance of Western IRT at the systemic level; the lack of awareness of "international-ness" at the local level; and the absence of "a theoretical hard core". ${ }^{20}$ In addition to local factors such as Indian IR studies' disciplinary location ${ }^{21}$

\footnotetext{
17 For, as it is well known in the long adventure of 'the revolt against the West', cultural revolt or protest against all forms of Western cultural imperialism is the last station following legal revolt against the West for equal sovereignty, political revolt to demand freedom from colonial domination, racial revolt to abolish slavery, and economic revolt against Western-dominated global commercial and financial systems. Hedley Bull, "The Revolt Against the West," in The Expansion of International Society, ed. Hedley Bull and Adam Watson (Oxford: Clarendon Press, 1984), 217-19. Although the "revolt against the West" was not initially a civilisational one, especially after the fifth phase it turned into one thanks to the returning of self confidence, largely as a result of the new economic strength which the non-Western countries gained.

18 Bull, "The Revolt Against the West," 223.

19 Bull, "The Revolt Against the West," 223-24.

20 Yaqing, "Why is there no Chinese International Relations Theory?," 322

21 Referring to IR being the product of conceptual conflation of Area Studies and disciplinary oriented IR, which results in the weakening of IR. Behera, "Re-imagining IR in India," 342-43.
} 
and pedagogical issues, ${ }^{22}$ Navnita Chadha Behera ${ }^{23}$ attributes the poor conceptualization of Indian IR mainly to the Gramscian hegemony which Western IRT has acquired over the epistemological foundations of the disciplinary core of Indian IRT. Although Takashi Inoguchi defines Japan as a great power and argues that "great powers often produce theories of IR," he explains the absence of Japanese IR theorization through Japan's embeddedness within the global governance system run by the sole superpower and "the relatively weak tradition of positivistic hypothesis testing in social science and the relatively strong tradition of describing details". ${ }^{24}$ Aydınl 1 and Mathews explain this situation at the structural level through the global division of labor between the core, which creates the theories and controls the agenda, and the periphery, which is on the receiving end of this division and has thus been reduced to the weak and subordinated partner. ${ }^{25}$ Arlene B. Tickner also explains the absence of NWIRT at the structural level with center-periphery relations and her pessimism about IR thinking in the periphery is the result of the existence of weak incentives to engage in theory-building at the local level. ${ }^{26}$ This is, on the one hand, due to many Latin American IR specialists' engagement with real-world problems making theory a useless luxury and, on the other hand, due to a sense of prestige being dependent on one's contribution to the policy world rather than dealing with theory. Pinar Bilgin makes similar observations about the absence of non-Western security studies that are also relevant for NWIRT. ${ }^{27}$ She remarks that, occupied with state-building, many non-Western elites have embraced the "standard" notion of security which is state-centric and national security-oriented, and have utilized it in building national security states. She also draws attention to how the Western-centric character of the discipline coincided with the modernization and/or Westernization projects of elites in various parts of the world. ${ }^{28}$

However, Alagappa, Inoguchi and Mallavarapu conclude that theory has not been totally absent from IR in, respectively, Asia, Japan and India, but that only theories with a positivist methodology or formal theorizing have been absent. ${ }^{29}$ Mallavarapu, similar to Bilgin and Tickner, explains the absence of formal theorizing in India with "the institutional settings that privilege policy work, a formative expectation that the role of social sciences including IR scholarship is to assist in the task of nation-building," and a "lack of familiarity, absence of a professional community of IR scholars, and the belief that theorizing is remote, irrelevant, and complicit with the imperial project". ${ }^{30}$ Alagappa, to explain the underdevelopment of formal IRT, notes four differences between Western and Asian IR communities. Similar to Aydınlı

22 Referring to 1) the late introduction of IR as a separate discipline at the M. Phil and Ph.D. levels only; 2) the lack of funds and infrastructure; 3) the absence of a well-knit community of Indian IR scholars who cumulatively tried to build a coherent edifice of work related to key IR disciplinary concerns and problems; and 4) the limitedness of career opportunities due to heavy workload, leaving little time for research. Behera, "Re-imagining IR in India," 343-44.

23 Behera, "Re-imagining IR in India," 341.

24 Inoguchi, "Are there any Theories of International Relations in Japan," 370

25 Aydınlı and Mathews, "Periphery Theorizing for a Truly Internationalized Discipline: Spinning IR Theory out of Anatolia," 694.

${ }^{26}$ Arlene B. Tickner, "Latin American IR and the Primacy of lo práctico," International Studies Review 10, no. 4 (2008): $735-48$.

${ }^{27}$ Pınar Bilgin, “The 'Western-Centrism' of Security Studies: 'Blind Spot' or Constitutive Practice?," Security Dialogue 41, no. 6 (2010): $615-22$

28 Bilgin, "The "Western-Centrism'," 618

29 Alagappa, "International Relations Studies in Asia," 221; Inoguchi, "Are there any Theories of International Relations in Japan," 383; Siddharth Mallavarapu, "Development of International Relations Theory in India: Traditions, Contemporary Perspectives and Trajectories," International Studies 46, no. 1-2 (2009): 165-83, cited in Alagappa, "International Relations Studies in Asia," 221.

${ }^{30}$ Mallavarapu, "Development of International Relations Theory in India," 221. 
and Mathews, he, firstly, points to center-periphery relations in the IR discipline, defining IR as "essentially a Western enterprise" in which "Asia matter[s] only on the margins," however he argues that "the rise of Asian countries and the emergence of Asia as a core world region with the potential to become the central world region have altered this situation". Secondly, he draws attention to the distinctive trajectories of Western and NWIR studies: While in the US and Europe the stimulation behind IR studies was to prevent the occurrence of great wars through legal-institutional means, in China, Japan, and India, IR studies were inaugurated to protect their newfound sovereignty and to consolidate their statehood in a world still dominated by Western powers. Thirdly, he refers to the extensiveness of state domination of public spheres in China, India, and Japan to explain these distinctive trajectories. ${ }^{31}$ And lastly, he points to the predominantly practical orientation of IRS in Asia to develop suitable policy responses. ${ }^{32}$

Acharya and Buzan attempt to explain the absence of NWIRT through cultural, political and institutional factors. ${ }^{33}$ In terms of a strong cultural explanation for the absence of NWIRT, they do not argue that "theory is a western way of doing things with others more inclined ....... [to study] local affairs" rather, they accept that being native speaker of English or living in a county where English is almost universally spoken may explain its absence. They further argue that a weaker version of the cultural explanation would be that theory, especially universal theory, is a luxury for societies struggling with pressing problems of development and that, by necessity, therefore focus on short-term local problem-solving. As a political factor, they argue that, "democracy is more of a necessary condition than a sufficient one" since "in the West, IRT has flourished most successfully in democracies". According to them, the third condition that may hinder the development of IRT is institutional factors, which refer to resourcing, workloads, career structures, and the intellectual ethos of those who might be expected to develop IRT. Acharya and Buzan in their later studies on NWIRT discuss five hypotheses for the absence of NWIRT: 1) the success of Western IR theory; 2) the hegemonic standing of Western IRT; 3) the hidden existence of NWIRT; 4) local conditions such as a paucity of institutions, journals, research cultures, career incentives, research resources, and training facilities; and 5) the West's head start. ${ }^{34}$

In contrast to Acharya and Buzan, I argue that, in the modern era, "theory is a Western way of doing things, ${ }^{35}$ yet, it is a matter of a feeling of superiority of Western experience and ways over others, more than a matter of culture. When their criteria for a work to be counted as a contribution to IRT (that it be acknowledged by others as being theory, that it be selfidentified by its creators as being IRT, that its construction identifies it as a systematic attempt to abstract or generalize about the subject matter of $\mathrm{IR}^{36}$ ) is taken into consideration, it is clear that theory construction requires self-confidence in what you represent. In other words, since one of the most basic functions of a theory is to provide a cognitive map or a mental model

31 Similarly, Makarychev and Morozov explain the absence of 'non-core' theory by arguing that ideological pressure on the social sciences in the Soviet Union put the middle-aged generation of Russian IR scholars in a comparative disadvantage vis-a-vis their Western colleagues. They also point out the difficulty of integrating into the international academic community overnight. Andrey Makarychev and Viatcheslav Morozov, "Is 'Non-Western Theory' Possible? The Idea of Multipolarity and the Trap of Epistemological Relativism in Russian IR,” International Studies Review 15, no. 3 (2013): 332-33.

32 Alagappa, "International Relations Studies in Asia," 195-97.

33 Acharya and Buzan, "Why is There No Non-Western International Relations Theory? An Introduction," 297-98.

${ }^{34}$ Amitav Acharya and Barry Buzan, Non-Western International Relations Theory: Perspectives On and Beyond Asia (London and New York: Routledge, 2010), 222-25.

${ }^{35}$ Acharya and Buzan, "Why is There No Non-Western International Relations Theory? An Introduction," 298.

36 Acharya and Buzan, Non-Western International Relations Theory, 292. 
for others that can be acknowledged by them as being theory, the absence of self-confidence would mean that let alone trying to construct theory, non-western intellectuals may even avoid seeing the intellectual need for doing so. As demonstrated by the parallelism between China's rise - resulting in regaining self-confidence - and the increasing efforts to construct Chinese perspectives in IRT, the efforts to develop NWIRT are more related to the overlap between intellectual motivations and maturation of political conditions.

Moreover, although I accept English as a linguistic barrier in non-English speaking countries, I claim that being a non-native English speaker can only partially explain why non-Western intellectuals' articles or books have been generally circulating less in the IR literature than those of Western intellectuals who are either native speakers of English or live in countries where English is almost universally spoken, yet it cannot specifically explain the absence of NWIRT production. Therefore I attribute the positive correlation that Acharya and Buzan observed between speaking English and flourishing of IRT to another factor, which I call intellectual soft balancing towards the United States. Given the fact that critical IRT has been articulated by Robert Cox (Canadian), Andrew Linklater (British), Richard Devetak (Australian), and critical security studies by Ken Booth (British), Richard Wyn Jones (British), Barry Buzan (British) and Ole Waever (Danish) who are either native speakers of English or live in countries where English is almost universally spoken, my argument sounds elucidative. In other words, rather than defining the West as a monolithic ideological block, I define it not only as internally fragmented but also composed of ideologically disputing parts that attempt to balance each other intellectually. Moreover, I argue that intellectuals that promote NWIRT, in particular NWIRT out of Asia and above all China, are potential allies against American hegemony over the discipline.

I find the weaker version of the cultural explanation, made by Acharya and Buzan, to be more reasonable; especially when problems related to nation-building are considered, it appears more compatible with explanations made by other scholars. ${ }^{37} \mathrm{I}$ also acknowledge the importance of the political factor that they underscored, however, for me the political factor, more than democracy, refers to a government's readiness for a theory that is not only compatible with national interests but also constructed from an authentic perspective.

Acharya's and Buzan's assumption that "foreign hegemony could be to induce in the local cultures a kind of radical demoralization and loss of confidence" ${ }^{98}$ to explain the absence of NWIRT is quite similar to what I call the trauma that intellectuals of once-supreme cultures have experienced, in other words, a sense of status deprivation and loss of self-confidence following their encounter with the West, at a time when they still deemed themselves to be superior in many respects.

Hence, I attribute the surfacing of NWIRT discussions in the last decades primarily to the maturation of an internal condition, that is, the revival of self-confidence in the residuals of former empires due to their regaining of rising power status, resulting in a new phase of the "revolt against the West." On the other hand, I believe that the rise of NWIRT discussions are also related to the ripening of an external condition. In this case, due to the disturbance created by the American hegemony within the IR discipline, some European schools of IR (the

${ }^{37}$ Mohammed Ayoob, "Inequality and Theorizing in International Relations: The Case for Subaltern Realism," International Studies Review 4, no. 3 (2002): 27-48; Mohammed Ayoob, "Challenging Hegemony: Political Islam and the North-South Divide," International Studies Review 9, no. 4 (2007) 629-43; Tickner, and Tsygankov, "A Sociology of Dependence,” 665; Bilgin, "The 'Western-Centrism' of Security Studies," 618; Alagappa, "International Relations Studies in Asia," 195.

38 Acharya and Buzan, Non-Western International Relations Theory, 297. 
English school, critical perspectives) have been trying to intellectually balance against the United States, and this balancing has reached its zenith with the publication of edited books and special issues on NWIRT as a potential ally. In short, the main argument of this article is that there have been at least three barriers blocking NWIR theorization: an intellectual one (the traumatizing effects of imposing the standard of civilization); an ideational/conceptual one (the dominance of Western concepts and contexts); and a scientific one (the standard of knowledge). These barriers have been established at the intersection of formal and informal colonization practices and the power-knowledge strategies of the West, which resulted in a recessive self-perception and what I call institutional camouflage strategies.

To show the traumatic effects of the encounter with the West, the next section turns to the cases of Qing China and the Ottoman Empire in order to explore the trauma of intellectuals in countries even only informally colonized.

\section{Intellectual Barriers: Traumatization of Non-Western Intellectuals with the Imposition of 'The Standard of Civilization'}

According to Acharya and Buzan, the historical trauma of World War I and World War II filled Western civilization with fear of the end of their own civilization and this fright eventually resulted in the growing need for a better understanding of peace and war around which the field of IR was institutionalized. They write that "if historical trauma is a necessary midwife for the birth of IR theory, then the experience of Western domination and decolonization should have been more than adequate to serve" ${ }^{39} \mathrm{I}$, however, argue that the nature of the historical trauma that Western societies had gone through and that non-Western societies have experienced is quite dissimilar and they each responded differently to their respective traumas. Firstly, the former's trauma was caused by intra-civilizational war whereas the latter's was introduced by another civilization which brought about not only military defeat but also psychological breakdown. Nora Fisher Onar also held that while the capitals, national identities and nation-states of Western European Empires were consolidated before or during the imperial enterprise, meaning that the loss of empire was not deeply disruptive to their core identity and institutions, for (Eur)Asian empires such as Turkey, China, Iran, and Russia, the process of imperial collapse was deeply traumatic as they declined over the course of extended encounters with Western nation-state empires whose military primacy, social and political organization, and capitalist mode of production compelled the pre-national (Eur) Asian empires to reconfigure their identity and institutions. ${ }^{40}$

I argue that both the discourses of modern vs. pre-modern, developed vs. undeveloped, civilized vs. barbarian, liberal vs. non-liberal, and the practices of imposing international law, capitulations, unequal treaty regimes and extraterritorial implementations as the standard of civilization (SOC) served to construct Western civilization as the superior one and to justify its direct or indirect imperial activities in non-Western countries, turning the encounter with Western civilization into a traumatic one. I also contend that this traumatic encounter not only divided these societies into three ideal typical categories of traditionalists, Westernists and synthesists ${ }^{41}$ that contradict one another regarding the method to be applied to ride out

Acharya and Buzan, "Why is there no non-Western International Relations Theory?," 297.

40 Nora Fisher Onar, "Historical Legacies in Rising Powers: Toward a (Eur)Asian Approach," Critical Asian Studies 45, no. 3 (2013): 413-15.

${ }^{41}$ Similar to Martin Wight (International Theory: The Three Traditions, ed. Gabriele Wight and Brien Porter (Leicester and London: Leicester University Press, 1991)) who rejected the idea that three traditions are "like pigeon holes," I accept that there 
the Western storm, but also led to identity reconstruction and state transformation in these societies following 1) technological, 2) institutional, and 3) cultural reforms. According to my ideal typical classification, traditionalists were anti-Westernist and, to a large extent, antimodernist since they explained the deprivation of status in relation to the Western powers or defeat by them substantially with the estrangement from authentic values, and therefore they offered to rediscover authentic values as a solution. Westernists, on the other hand, attributed the traumatic encounter with the West to being out of touch with developments or inability of keeping up with the pace of change, so they were both pro-Westernist and promodernist. They supported technological, institutional and cultural reforms and especially emphasized the need for a cultural revolution to realize the first two. Synthesists adopted an in-between strategy to cope with the trauma and that is why they were anti-Westernist but not generally anti-modernist. They endorsed technological/military reforms and to some extent institutional reforms, yet, they were certainly against extensive cultural reforms.

As Westernists and traditionalists expended considerable amounts of energy on fighting each other over different solutions they created to cope with the Western challenge, some scholars have defined these countries as 'torn' between traditionalists and Westernists. ${ }^{42}$ I infer that while Western countries learned to benefit from their civilization's various sources, non-Western countries ended up with a "broken genealogy of intellectual culture,"43 and lost their self-confidence significantly, therefore imitation of the powerful was embraced by them as a survival strategy.

The analysis of Klebleyev, inspired by DiMagio and Powell, is helpful in comprehending the rationality behind the imitation of the powerful: ${ }^{44}$

\begin{abstract}
Isomorphic mimicry is a biological term that signifies a process in which one organism imitates the other in order to gain evolutionary advantage. Similarly, organizations or even whole countries could choose to imitate the outer appearance of mainstream PA [Public Administration] systems driven by the desire to secure legitimacy, pressured to conform to institutional structures of the more powerful countries and giving-in to the normative influences of professional associations. ${ }^{45}$ (emphasis added)
\end{abstract}

He also argues that while the drive for competitive isomorphism to a large extent has been a voluntary act to be able to compete with the technological superiority of the West, institutional isomorphism is the result of three necessities: "the desire to gain legitimacy (coercive isomorphism), dealing with uncertainty (mimetic processes), and responding to the normative pressures exerted through formal education and professional networks". ${ }^{46} \mathrm{I}$ reconceptualize "institutional isomorphisms" as institutional camouflage resembling Acharya and Buzan's statement that "East Asia may be dressed up in Westphalian costume, but not

exists variability within traditions and I use three traditions just for analytical simplification. Tsygankov and Tsygankov also define three ideologies of 19th century Russia as Westernists, Statists, and Civilizationists which have been reincarnated in the postSoviet context as, respectively, Liberals, Realists and Cultural Essentialists or Constructivists. Andrei Tsygankov and P. Tsygankov, "National Ideology and IR Theory: Three Incarnations of the 'Russian Idea'," 678. Onar similarly defines three responses that were developed from Istanbul to Beijing for "the challenge posed by European-cum-Western modernity":"Eurocentrism (e.g., will to (Western) civilization; negation of Asiatic "backwardness"); Occidentalism (e.g., condemnation of Western decadence; lauding of Asian virtue); and multiple modernities of (e.g., hybrid - and commodified-"Western" and "Asian" motifs)". Onar, "Historical Legacies in Rising Powers," 419-21.

42 Samuel Huntington, The Clash of Civilizations and the Remaking of World Order (New York: Simon and Scuster, 1996.)

43 Yaqing, "Why is there no Chinese International Relations Theory?" 324.

44 P.J. DiMagio and W.W. Powell, "The Iron Cage Revisited: Institutional Isomorphism and Collective Rationality in Organizational Fields," American Sociological Review 48, no. 2 (1983): 147-60.

45 Klebleyev, "Islamic Legacy beyond Islam," 144.

46 Klebleyev, "Islamic Legacy beyond Islam," 148. 
performing a Westphalian play". ${ }^{47}$

Although Homi Bhabha's chapter on "Of Mimicry and Man: The Ambivalence of Colonial Discourse" is well known in the colonial literature, he uses mimicry generally to explain the colonized non-white peoples' relations with the Western colonizer. Instead of Fanon's 'turn white or disappear', he draws attention to "the more ambivalent, third choice: camouflage, mimicry, black skins/white masks," 48 and to explain the relation between camouflage and mimicry he refers to Lacan:

The effect of mimicry is camouflage, in the strictly technical sense. It is not a question of harmonizing with the background but, against a mottled background, of being mottled exactly like the technique of camouflage practised in human warfare. (emphasis is mine) ${ }^{49}$

However, as I note, informally colonized states that are the inheritors of former empires (such as the Peoples Republic of China, the Republic of Turkey, as well as the Russian Federation and the Islamic Republic of Iran) should be handled differently from formal colonies, because although these countries' encounters with the West were also traumatic since they experienced a status deprivation in relation to Western great powers and their self-esteem got wounded, they have resorted to mimicry as a camouflage strategy only to gain time to close the technological and economic development gap for the (re)establishment and survival of their states. Their official aims, however, in their relations with the West can be summarized as "surpassing the level of contemporary civilization" rather than only catching up with it. Actually, both China's and Turkey's development objectives for the $100^{\text {th }}$ anniversary of the establishment of their Republics respectively in 2049 and in 2023 can be read as the reflection of this strategy of mimicry as a camouflage, that aims at surpassing the standards of Western civilisation that were imposed upon them.

If I turn back to analyses of Klebleyev, the first drive for institutional isomorphism is to gain legitimacy in the eyes of Western powers which impose formal and informal pressures on non-Western countries to ensure their conformity. It can be argued that since the challenges posed by Western civilization had military, socio-political and cultural aspects, the reforms made by Qing China and the late Ottoman Empire also follow this sequence:

[Q]ing China, Siam, and the Ottoman Empire...each underwent a process of state transformation: a mixture of deliberate reforms and ad hoc responses to necessities created by foreign threats and internal administrative, economic, and military problems. Each restructured its military and imported modern European weaponry, ... Each gradually instituted reforms to make its central government more nearly fit European categories and expectations: the Ottomans in the 1860s and 1870s, Siam in the 1880s and 1890s, and Qing China during the post-Boxer reforms. ${ }^{50}$

In other words, 'the loose pattern of the progression' of the reforms made by Qing China and the late Ottoman Empire, beginning with self-strengthening military reforms, followed by much more systematic efforts of legal reforms and adaptation to European patterns of government reaching their zenith with cultural reforms, ${ }^{51}$ reflects their preoccupation with gaining legitimacy in the eyes of Western states, given the SOC imposed by them.

\footnotetext{
${ }^{47}$ Acharya and Buzan, "Why is There No Non-Western International Relations Theory?," 291.

48 Bhabha, The Location of Culture, 120.

${ }^{49}$ Cited in Bhabha, The Location of Culture, 120-21.

${ }_{50}$ Richard H. Horowitz, "International Law and State Transformation in China, Siam, and the Ottoman Empire during the Nineteenth Century," Journal of World History 15, no. 4 (2005): 445-86.

51 Horowitz, "International Law and State Transformation," 458-59.
} 
The SOC requires that non-Western countries treat Western citizens according to Western legal standards and that non-Western countries become 'civilized' in order to join the international society of states. To be a member of the 'Westphalian civilization,' non-Western countries had to:

(1) guarantee basic rights, as understood in the West, for foreign nationals; (2) have an organized political bureaucracy with the capacity to run governmental functions and organize the country for self-defense; (3) have a Western-style domestic system of law, with courts and written codes of law...; (4) have diplomatic resources and institutions to allow the state to engage in international relations; (5) abide by international law; (6) conform to the customs, norms, and mores accepted in Western societies..$^{52}$

In other words, the SOC was assuming a new hierarchy of states among the civilized, the barbarous, and the savage ones and it was supposed that international law applied fully only to the first in the list. ${ }^{53}$ Surely, the hierarchy in international relations was not invented by Western civilization. Qing China and the Ottoman Empire also maintained their own hierarchical relations based on their own values, and as far as they remained strong enough in the face of European states, they resisted accepting a new hierarchy other than their own.

As Andrew Phillips argues, Mughal India and Manchu China, along with the Europeans, resorted to civilizing missions to legitimize their military superiority, however while Mughal and Manchu civilizing missions were "processes of cultural synthesis and hybridization," European civilizing missions were "a mere exercise in one-way cultural imperialism". ${ }^{54}$ He further defines six characteristics that are truly distinctive about the classical Western civilizational standard that prevailed in the $19^{\text {th }}$ and early $20^{\text {th }}$ centuries:

1) Unstable pairing of sovereign equality alongside imperial hierarchy...,2) the contradictory coexistence of rights-based moral universalism with ideas of racial supremacy..., 3) anchoring of civilizing missions within positive international law..., 4) the obsession with standardization and proselytisation over customization and cultural bricolage..., 5) the West's pervasive stress on technology as a marker of civilisational supremacy..., 6) unusual exclusivis(m) compared to its historical predecessors. ${ }^{55}$

These are reflections of the all-pervasive character of Western dominance that Hedley Bull in his famous chapter on "Revolt against the West" also similarly defines in terms of their economic and military superiority, their commanding intellectual and cultural authority as well as establishing the rules and institutions of international society that were in substantial measure made for them. He further argues that although, around the year 1900, Western impact on the world was in many respects less far-reaching than it has since become, the dominance of the European and Western powers expressed a sense of self-assurance, both about the durability of their position in international society and about its moral purpose. $\mathrm{He}$ states that even in non- Western societies the ascendancy of the West was widely regarded as something which couldn't or shouldn't be changed. ${ }^{56}$

Barry Buzan also remarks on "the emergence of a new colonial regime" in the middle of the $19^{\text {th }}$ century that led "the European states [to begin remaking] the colonies in their

\footnotetext{
52 David P. Fidler, "The Return of the Standard of Civilization," Chicago Journal of International Law 2, no. 1 (2001): 141.

53 Horowitz, "International Law and State Transformation," 453-54.

54 Andrew Phillips, "Civilizing Missions and the Rise of International Hierarchies in Early Modern Asia," Millennium: Journal of International Studies 42, no. 3 (2014): 714.

55 Phillips, "Civilizing Missions and the Rise of International Hierarchies," 715-16.

56 Bull, "The Revolt Against the West," 217-19.
} 
own image". And he associates this new colonial regime, on the one hand, with "the contemporaneous move from universal natural law to the adoption of positivist law," and on the other hand, with "the general take-off of modernity" that "opened up a huge power gap between a mainly European core and a mainly non-Western periphery and transformed the raison de système". ${ }^{57}$

Hence, as Europeans became stronger, both the Ottoman Empire and Qing China felt more obliged to accede to European standards. At the implementation of the SOC, capitulations ${ }^{58}$ were one of the primary tools employed by Western countries. ${ }^{59}$ Although, initially, the capitulations were voluntarily bestowed by the Ottoman Sultans familiar with plural legal systems, after they began being supplemented by a treaty system in the 1830s and 1840s, these voluntarily bestowed capitulations turned into an obligation. By 1860, similar unequal treaty arrangements were also concluded with the Qing Dynasty, with the treaties signed between 1842 and 1860 that established extraterritoriality and related arrangements until the mid-twentieth century. ${ }^{60}$ Therefore, one can infer that Qing China and the late Ottoman Empire were coerced by European countries to promote international trade with themselves through unequal treaty relations. ${ }^{61}$ With the Anglo-Ottoman commercial treaty of Balta Limanı signed in 1838, the Ottomans conceded what amounted to free trade. The Ottomans also agreed to the abolition of all monopolies. ${ }^{62}$ There were other developments -the law regarding foreigners' right to purchase properties in Ottoman lands (1858), the sea trade agreement (1864), and the regulations about trade courts and jurisdictions (1862) - in the period between the Islahat Fermanı and the first constitution of 1876, which opened the Ottoman political, economic, and social space even further to European influence. ${ }^{63}$ After the Opium Wars (1839-42), a trade agreement similar to Balta Limanı was forcibly signed between China and Britain, which reopened opium imports, abolished the monopoly of the foreign trade guild known as the Cohong, and sought to bring customs rates under control. ${ }^{64}$ The Second Opium War strengthened the enforcement of a free trade regime in the late $1850 \mathrm{~s}$ and, subsequently, the Imperial Maritime Customs Service institutionalized the free-trade element of the treaty system within the Qing state itself. ${ }^{65}$

However, the most direct impact on both the Ottoman and Qing states came from foreign debts. ${ }^{66}$ In 1881, an agreement between the Sublime Porte and foreign creditors created the Public Debts Administration (Duyun-u Umumiye). It was foreign controlled and foreign run, controlled the major portions, arguably "27 percent of Ottoman revenue," ${ }^{\prime 67}$ and constituted

\footnotetext{
57 Barry Buzan, An Introduction to the English School of IR (Cambridge: Polity, 2014), 64.

58 The capitulations were agreements between various states and the Ottoman Empire that codified the conditions and arrangements that allowed foreign merchants to live and operate in the Ottoman Empire. Savage, "The Stability and Breakdown of Empire," 173.

59 Fidler, "The Return of the Standard of Civilization," 142.

60 Horowitz, "International Law and State Transformation," 459, 461.

${ }_{61}$ Although treaties were technically agreements between equal and consenting states, as they travelled eastward they became unequal in several aspects: "They were forced at gunpoint; they expressed the economic and political interests of Britain and other powers; and key provisions, including extraterritoriality and restrictions on tariffs on foreign trade, were not reciprocal," Horowitz, "International Law and State Transformation," 455.

62 Horowitz, "International Law and State Transformation," 470.

${ }^{63}$ Ersel Aydinlı, "The Turkish Pendulum between Globalization and Security: From the Late Ottoman Era to the 1930s," Middle Eastern Studies 40, no. 3 (2004): 107.

${ }_{64}$ Horowitz, "International Law and State Transformation,” 470; Ahmet Emre Biber, "Osmanlı İmparatorluğu'nun dünya sistemine eklemlenme süreci ve azgelişmişliğin evrimi,” Uluslararası İnsan Bilimleri Dergisi 6, no. 1 (2009): 32.

65 Horowitz, "International Law and State Transformation," 470.

${ }_{66}$ Between 1854 and 1875 during the heyday of the reforms the Ottomans had take 16 times foreign dept. Biber, "Osmanl İmparatorluğu'nun Dünya Sistemine Eklemlenme Süreci," 37.

${ }_{67}$ M. S. Hanioglu, A Brief History of the Late Ottoman Empire (Princeton, NJ: Princeton University Press, 2008), cited in
} 
an enormous incursion on Ottoman sovereignty ${ }^{68}$ Similarly in China, foreign debt became a serious problem after 1895, due to the enormous indemnity from the war with Japan. After the fall of the Qing Dynasty in 1912, Yuan Shikai's government contracted the infamous Reorganization Loan, similar to Duyun-u Umumiye, which conceded the salt monopoly to a foreign administration. ${ }^{69}$

The second motivation behind institutional isomorphism, according to Klebleyev, has been 'mimicry', which is described as "when dealing with ambiguous goals or an uncertain environment, organizations often choose to model other successful organizations instead of creating their own solutions". ${ }^{70}$ In other words, under uncertain conditions (especially when self-confidence is lost), intellectuals may also prefer to imitate successful models instead of creating new ones by taking a risk. I contend that imitation as a survival strategy has locked non-Western intellectuals into "the theory-learning phase' ${ }^{71}$ for a long time (certainly not forever as one can observe from the growing discussions in the literature) in which intellectuals focus on introducing, testing and critically analyzing major Western theories rather than developing non-Western theories or studying from pre-theoretical local resources.

The third motivation behind institutional isomorphism, asserted by Klebleyev, is the normative influence of formal education and professional networks, which refer to the employment of civil servants and government officials who are socialized solely with Western-centric education in government positions in numerous non-Western countries. Certainly, even behind this Western-centrism lies the survival reflex in a world where Western values are dominant. ${ }^{72}$ On the other hand, Savage explains the accommodative elite attitude towards informal empire through benefits the elites receive and necessities imposed by a decentralized political system. Savage indicates that, despite the existence of certain compelling disincentives such as loss of autonomy and potential exploitation, Empire allows for beneficial economic flows from the core through international trade, which enables wellsituated peripheral actors to capture rents or gain financing and technology transfer that can also be used in conflicts with other domestic actors. ${ }^{73}$ His analyses about the effects of elite preferences on the continuation of informal empire are compatible with Bilgin, who attempts to explain "the dynamics behind the persistence of mainstream security studies outside the 'West'". She remarks that many non-Western elites have embraced the Western 'standard' notion of security to utilize it in building national security states which is a part of their Westernization projects. ${ }^{74}$

I infer that the imposition of the SOC by Western powers as an instrument of coercive isomorphism resulted in learned exhaustion to not create something new which can be disruptive to the harmony with the West and, therefore, cause the delegitimization of the development processes. The efforts of developing nations to copy Western administrative practices and the level of mimicking everything European, including looking 'modern,' showcases the energy expended on securing the legitimacy and recognition of European powers, as well as, the access to funds by non-Western countries. ${ }^{75}$

\footnotetext{
Savage, "The Stability and Breakdown of Empire," 162.

68 Biber, "Osmanlı İmparatorluğu'nun Dünya Sistemine Eklemlenme Süreci," 36-8, Horowitz, "International Law and State Transformation," 473.

69 Horowitz, "International Law and State Transformation," 473-74.

70 Klebleyev, "Islamic Legacy beyond Islam," 148.

71 Yaqing, "Why is there no Chinese International Relations Theory?," 318

72 Klebleyev, "Islamic Legacy beyond Islam," 148.

73 Savage, "The Stability and Breakdown of Empire," 168.

74 Bilgin, "The 'Western-Centrism' of Security Studies," 618.

75 Klebleyev, "Islamic Legacy beyond Islam," 148.
} 


\title{
4. Conceptual/Ideational Barriers: The West's Power to Define Concepts and the Context of IR
}

Thomas Szasz declares that "In the animal kingdom, the rule is, eat or be eaten; in the human kingdom, define or be defined" ${ }^{76}$ Similarly, Karl Deutsch defines power as "the priority of input over intake, the ability to talk instead of listen ... the ability to afford not to learn". 77 Inspired by both Szasz and Deutsch, I reformulate the most quoted sentence of the Melian Dialogue as "the strong define what they can and the weak consent to what they must" and I suggest that who defines the concepts, also decides the context and the agenda of the literature. ${ }^{78}$

Therefore, mainstream IR perspectives have been blind to gender and economic inequalities, as well as to the questions of migration, the environment, human rights and cultural clashes, as the main focus stays on political and military inequalities. ${ }^{79}$ Similarly, the traditional conceptualization of national security ties security to military strength and limits it with physical protection of the nation state from external threats. This partial definition of security is also blind to numerous real security threats, such as the satisfaction of basic material needs and lower life expectancy by virtue of one's place of birth. ${ }^{80}$

Another common defect of mainstream conceptualizations is overlooking the differences, either due to reducing 'the other' to threat or due to perceiving it as surmountable in a culturally homogenous global society, which led Tsygankov to complain:

\begin{abstract}
Much like modernization theory that historically assisted the state in justifying its colonial practices, theory of international relations offers no reciprocal engagement with the Other and merely expects the Other to follow the West's lead. Western IR theory allows little conceptual space for 'non-Western' theorists treating them as dependent subjects ('subalterns') and consumers of the already developed knowledge. ${ }^{81}$
\end{abstract}

In other words, at the roots of psychological restlessness of Non-Western intellectuals lies, in the words of Nandy, the West's "power to define," ${ }^{2}$ which gives even the privilege of defining the key problems of the Third World to Western scholars. Thus, Behera finds a significant correlation between the absence of NWIRT and the dependence of the Third World on the master narrative written by the West:

\footnotetext{
The fact that nearly six decades later, many still characterize themselves as 'developing' countries shows how deeply the western definition of the third world has penetrated their collective psyche... [ W] hy traditional IR in India has not, indeed, could not produce a nonwestern IR theory is because it has fought that intellectual battle on a turf chosen by the west, with tools designed and provided by the west and rules-of-game set by the west enforced, as they were, by not just its political and military might but more importantly, its all-pervasive discursive power. ${ }^{83}$
}

${ }^{76}$ Cited in Behera, "Re-imagining IR in India," 360.

77 K.W. Deutsch, The Nerves of Government (New York: The Free Press of Glencoe, 1963), 111, cited in Klebleyev, "Islamic Legacy beyond Islam," 146.

78 "The strong do what they can and the weak suffer what they must."

79 Smith, "The United States and the Discipline of International Relations," 82.

80 J. Ann Tickner, "A Critique of Morgenthau's Principles of Political Realism," in International Politics: Enduring Concepts and Contemporary Issues, eds. Robert J. Art and Robert Jervis (New York: Longman, 2005), 21.

${ }_{81}$ Andrei P. Tsygankov, "Self and Other in International Relations Theory: Learning from Russian Civilizational Debates," International Studies Review10, no. 4 (2008): 763-64.

${ }_{82}$ Ashis Nandy, The Savage Freud, reprinted in Nandy: Return From Exile (New Delhi: Oxford University Press, 1998), cited in Behera, "Re-imagining IR in India," 354.

${ }_{83}$ Nandy, The Savage Freud, 354. 
That is why I stress that the silence ${ }^{84}$ of NWIRT results primarily from 'mimicking the West' due to both the traumatic encounter with it and the "harmony of interest" 85 between the West as the center and Westernist elites as the periphery's centers. This harmony of interest is reflected in Westernist elites' enthusiasms for cultural accommodation with the West. For, during this cultural imitation phase of modernization process, European powers and Westernists in periphery nations agree upon disdain for people's values, cultures and beliefs supposing that these are significant obstacles to modernization. This results in viewing cultural heritages of non-Western countries as an impediment to modernization, while Western countries construct officially their history in a coherent and complementary progressive line from Ancient Greece to the Hellenic world, from Roman tradition to Christianity to modern times.

Ziauddin Sardar thus argues that non-Western cultures need to "define their own future in terms of their own categories and concepts and to articulate their visions in a language that is true to their own Self, even if not comprehensible 'on the other side of the global fence of academic respectability" ${ }^{86}$ Siddharth Mallavarapu also associates the question of postWestern IR theorization with the challenge of introducing new concepts and categories. He emphasizes the need to amalgamate various local approaches to overcome ethnocentrism in IR and to avoid a monolithic conception of IR emerging from one country only. ${ }^{87}$ Likewise, Madina Tlostanova claims, "In order to overcome the persistent Orientalism -both coming from the West and the internal self-Orientalizing stance- it is necessary to de-colonize the thinking itself, to get rid of the absolute Western scholarly paradigms and myths..." 88

\section{Scientific Barriers: Power of Defining the Standard of Science}

Smith states that mainstream IR defines the appropriate methods of how to study international relations in such a narrow way, "insisting on positivist assumptions," that it restricts understanding of other cultures and rationalities. ${ }^{89}$ Alagappa, too, underlines that, despite challenges from contending theoretical perspectives, rationalism and positivism continue to dominate IR theory both in the United States and in Europe..$^{90}$ Tickner and Wæver also argue that the roots of American IR's hegemony lie in the "authority over decisions concerning what qualifies as theory". ${ }^{91}$ Meshari Alruwaih, in a contribution to the discussion on methodology, further stresses that empirical epistemology and instrumentalism shield the 'pre-theory' and "tell us what to look at and what to look for, thus they organize and order our experience when observing IR. Equally important, they tell us what to ignore: human agency, belief systems, normative structure..." ${ }^{92}$ Hence, according to the hegemonic standard of

\footnotetext{
84 Similarly Behera, in her analysis of Indian IR's silence towards Indian history, supports the idea that silence is an "adaptive response to domination" and attributes this silence to "Following the footsteps - metaphorically and substantively - of its "Master Creator" (read western IR)." "Re-imagining IR in India," 352.

85 Johan Galtung, “A Structural Theory of Imperialism," Journal of Peace Research 8, no. 2 (1971): 81 -117.

${ }^{86}$ Ziauddin Sardar, "Introduction: The A, B, C, D (and E) of Ashis Nandy," in Return from Exile: Ashis Nandy (New Delhi: Oxford University Press, 1998): 23 cited in Behera, "Re-imagining IR in India," 360.

${ }^{87}$ Siddharth Mallavarapu Theory Talks, 2014, http://www.isn.ethz.ch/Digital-Library/Articles/Detail?id=180583, cited in Shahi and Ascione, "Rethinking the Absence of post-Western International Relations Theory in India," 316.

${ }_{88}$ Madina Tlostanova, "The Janus-Faced Empire Distorting Orientalist Discourses: Gender, Race and Religion in the Russian/ (post)Soviet Constructions of the 'Orient'," cited in Makarychev and Morozov, "Is 'Non-Western Theory' Possible?," 334.

89 Smith, "The United States and the Discipline of International Relations," 67.

90 Alagappa, "International Relations Studies in Asia," 201.

91 Arlene Tickner and Ole Wæver, "Conclusion: Worlding where the West once was," in Tickner and Wæver, International Relations Scholarship, 335.

${ }_{92}$ Meshari Alruwaih, "The Agency of the Muslim IR Researcher in Developing a Theory of Islamic Agency in International Relations," Asia Politics and Policy 7, no. 1 (2015): 47
} 
science, reflectivist theories, including the non-Western ones, either seem irrelevant to the concerns of the 'real' world, or even worse, are accused of not being part of the social science enterprise. ${ }^{93}$ Behera, therefore, insists that the "West's assumed right to impart legitimacy on all knowledge systems, that is, determining which 'ways of creating knowledge; are legitimate and which are not..." needs to be questioned. ${ }^{44}$ She names this standard of science as an 'epistemic violence' in reference to Spivak and complains about the silencing of Indian conceptualization of nationalism due to this standard..$^{95}$

Alruwaih, to eliminate the scientific barrier, suggests that Muslim IR researchers "free [their] own agency and social activity of seeking knowledge from the foundational commitments that underline knowledge production in the western discipline of IR". ${ }^{96}$ Shahi and Ascione, defining the aim of post-Western IR theory as "breaking epistemological imperialism in IR," note that "the transformation of the Eurocentric epistemological base of IR, without inadvertently generating a 'derivative discourse' of Western IR, requires an intellectual flight over rigid boundaries of Western scientism..." ${ }^{97}$ Tsygankov also argues that in contrast to ethnocentric, or excessively pro-Western theories, to establish an IR discipline taking the Other seriously necessitates "committing to assumptions of the Other's equality to the Self in terms of defining parameters and boundaries of knowledge". ${ }^{98}$ Therefore, since "there are lots of alien ways of producing knowledge," we should give ear to the "the wisdoms of other civilizations which are wonderfully and creatively "unscientific". 99

\section{Conclusion}

Western centric mainstream IRT's perception of their theoretical constructions as standard models that can be applied in different contexts, and the considerable internalization of this perception especially by the Westernists in various countries as a strategy of isomorphism, can be reasonably defined as the main obstacle to the construction of NWIRT. In other words "the twin working of civilizational projects of colonialism and modernity ...[which] reproduced and sustained each other" 100 indicates the cooperation between the West and the Westernist elites to construct the basic institutions of modernity, including the nation-state, science, and secularism, as well as the ideational structures of IRT, as universally acceptable ideal forms. But one of the most important motivations behind the imitation is, as I argued before, institutional camouflage for the (re)establishment and the survival of non-Western states after their traumatic encounter with the Western states. Therefore, discourses of "coming in tune with the "spirit of the age" 101 or "catching up with the level of contemporary civilization," significantly reflect the psychological restlessness stemming from, on the one hand, the perception of 'running behind' as a result of the internalization of the linear progressive paradigm in history, and on the other hand, the fear of engulfment by the great powers.

I also acknowledge the difficulty of constructing NWIRT arising from the fact that "Western IRT .... contain[s] a very wide range of approaches, which makes it quite difficult

93 Smith, "The United States and the Discipline of International Relations" 72.

94 Behera, "Re-imagining IR in India," 360.

95 Behera, "Re-imagining IR in India," 351.

${ }^{96}$ Alruwaih, "The Agency of the Muslim IR Researcher," 54.

${ }_{97}$ Shahi and Ascione, "Rethinking the Absence of Post-Western International Relations Theory in India," 314.

98 Tsygankov, "Self and Other in International Relations Theory," 764.

99 Amitav Acharya, "Dialogue and Discovery: In Search of International Relations Theories beyond the West," Millennium: Journal of International Studie 39, no. 3 (2011): 636.

${ }^{100}$ Nandy cited in Behera, "Re-imagining IR in India," 357.

${ }^{101}$ Jawaharlal Nehru, An Autobiography (New Delhi: Penguin Books, 2004), cited in Behera, "Re-imagining IR in India," 352. 
to outflank with something wholly new, especially so long as the brute fact of the Western style of international political economy continues to dominate real existing international relations". ${ }^{102}$ However, since I explain the absence of NWIRT substantially with the loss of self-confidence due to the traumatic encounter with Western civilization and with isomorphic mimicking as a strategic response to the Western challenge, as self-confidence was regained and more courageous strategies were developed with the aid of restored power, one can reasonably expect that the efforts for non-Western theorizing may increase. Indeed, the rise of theory with Chinese characteristics ${ }^{103}$ that I assume to be reflecting the rise of China and corresponding gain of self-confidence support this expectation. Therefore accelerating NWIRT discussions in the last decades, on the one hand, can be attributed to the revival of self confidence in the residuals of former empires thanks to the recovery of rising power status that resulted in a new intellectual "revolt against the West", on the other hand, can be attributed to some European schools of IR's attempts to intellectually balance against the hegemony of American mainstream via an intellectual alliance with NWIRT.

Nevertheless, similar to Tsygankov, who emphasizes the necessity of "recognizing the existence of the delicate dialectical balance between cultural pluralism and diversity, on the one hand, and the increased commonness of humanity, on the other" ${ }^{104}$, I maintain that we do not have to make a choice between universal vs exceptionalist or systemic vs subsystemic IRT. Inspired by Drechsler's formulation for good public administration, I also assert that a non-hegemonic discipline may well bring together the systemic, the semi-systemic and the sub-systemic elements. His formulation joins three elements across three levels: 1) a tiny, well-working common nucleus (systemic/universal); 2) a larger one composed from generally valid principles (semi-systemic/unilocal); and 3) solutions or explanations specific to a given paradigm or a sub-system (subsytemic/local). ${ }^{105}$

To translate IRT from almost a hegemonic structure to a good balanced one that brings together a tiny common nucleus with the semi-systemic and the sub-systemic elements, I suggest that we should attempt to construct universal models inspired by different ideas, thoughts, beliefs, interests and sometimes feelings of different localities as well as diverse cultural, regional, religious experiences. Chen argues that "simply calling for greater incorporation of ideas from the non-West and contributions by non-Western scholars from local 'vantage points' does not make IR more global or democratic, for that would do little to transform the discipline's Eurocentric epistemological foundations." ${ }^{106}$ Nevertheless, I believe that discovering or producing indigenous perspectives of IR may help to establish a balance of trade between systemic/universal level and subsytemic/local level and even may help to transform the discipline into a less hegemonic one.

\footnotetext{
${ }^{102}$ Acharya and Buzan, Non-Western International Relations Theory, 236.

${ }_{103}$ There are hundreds of articles and tens of books on this issue but I can refer only to some of the most well known of them: Zhao Tingyang, "Rethinking Empire from a Chinese Concept 'All-under-Heaven' (Tian-xia)," Social Identities 12, no. 1 (2006): 29-41; David C. Kang, "Hierarchy and Legitimacy in International Systems: The Tribute System in Early Modern East Asia," Security Studies 19, no. 4 (2010): 591-622; Yaqing Qin, "Relationality and Processual Construction: Bringing Chinese Ideas into International Relations Theory," Social Sciences in China 30, no. 3 (2009): 5-20; Yongjin Zhang and Barry Buzan, "The Tributary System as International Society in Theory and Practice," Chinese Journal of International Politics 5, no. 1 (2012): 3-36; Feng Zhang, "Rethinking the 'Tribute System': Broadening the Conceptual Horizon of Historical East Asian Politics," Chinese Journal of International Politics 2, no. 4 (2009): 545-74.

${ }^{104}$ Andrei Tsygankov, “The Irony of Western Ideas in a Multicultural World: Russians' Intellectual Engagement with the 'End of History' and 'Clash of Civilizations'," International Studies Review 5, no. 1 (2003): 70.

${ }^{105}$ Wolfgang Drechsler, "What is Islamic Public Administration and Why Should We Study it in the "Second World'?," Administrative Culture 15, no. 2 (2014): 130

${ }^{106}$ Chen, "The Absence of Non-Western IR theory in Asia Reconsidered," 1.
} 


\section{Bibliography}

Acharya, Amitav. "Dialogue and Discovery: In Search of International Relations Theories beyond the West." Millennium: Journal of International Studies 39, no. 3 (2011): 619-37.

Acharya, Amitav, and Barry Buzan. "Why is There No Non-Western IR Theory? An Introduction." International Relations of the Asia-Pacific 7, no. 3 (2007): 287-312.

Acharya, Amitav, and Barry Buzan, eds. Non-Western International Relations Theory: Perspectives on and Beyond Asia. London and New York: Routledge, 2010.

Adelson, Leslie A. "Touching Tales of Turks, Germans, and Jews: Cultural Alterity, Historical Narrative, and Literary Riddles for the 1990s." New German Critique no. 80 (2000): 93-124.

Alruwaih, Meshari. "The Agency of the Muslim IR Researcher in Developing a Theory of Islamic Agency in International Relations.” Asian Politics and Policy 7, no. 1 (2015): 39-56.

Alagappa, Muthiah. "International Relations Studies in Asia: Distinctive Trajectories." International Relations of the Asia Pacific 11, no. 2 (2011): 193-230.

Appadurai, Arjun. Modernity at Large: Cultural Dimensions of Globalization. Minneapolis: University of Minnesota Press, 1996.

Aydınl, Ersel. "The Turkish Pendulum between Globalization and Security: From the Late Ottoman Era to the 1930s.” Middle Eastern Studies 40, no. 3 (2004): 102-33.

Aydınl, Ersel, and Julie Mathews. "Periphery Theorizing for a Truly Internationalized Discipline: Spinning IR Theory out of Anatolia.” Review of International Studies 34 (2008): 693-712.

Ayoob, Mohammed. "Challenging Hegemony: Political Islam and the North-South Divide." International Studies Review 9, no. 4 (2007): 629-43.

- "Inequality and Theorizing in International Relations: The Case for Subaltern Realism." International Studies Review 4, no. 3 (2002): 27-48.

Behera, Navnita Chadha. "Re-imagining IR in India." International Relations of the Asia Pacific 7, no. 3 (2007): 341-68.

Bhabha, Homi K. The Location of Culture. London: Routledge, 1994.

Biber, Ahmet Emre. "Osmanlı İmparatorluğu'nun dünya sistemine eklemlenme süreci ve az gelişmişliğin evrimi." Uluslararası İnsan Bilimleri Dergisi 6, no. 1 (2009): 27-44.

Bilgin, P1nar. "The 'Western-Centrism' of Security Studies: 'Blind Spot' or Constitutive Practice?" Security Dialogue 41, no. 6 (2010): 615-22.

Bull, Hedley. "The Revolt Against the West.” In The Expansion of International Society, edited by Hedley Bull and Adam Watson, 217-28. Oxford: Clarendon, 1984.

Buzan, Barry. An Introduction to the English School of IR. Cambridge: Polity, 2014.

Chen, Ching-Chang. "The Absence of Non-Western IR theory in Asia Reconsidered." International Relations of the Asia Pacific 11, no. 1 (2011): 1-23.

DiMagio, Paul J., and Walter W. Powell. "The Iron Cage Revisited: Institutional Isomorphism and Collective Rationality in Organizational Fields.” American Sociological Review 48, no. 2 (1983): 147-60.

Drechsler, Wolfgang. "What is Islamic Public Administration and Why Should We Study it in the 'Second World'?" Administrative Culture 15, no. 2 (2014): 123-42.

Fidler, David P. “The Return of the Standard of Civilization.” Chicago Journal of International Law 2, no. 1 (2001): $137-57$.

Galtung, Johan. “A Structural Theory of Imperialism.“ Journal of Peace Research 8, no. 2 (1971): 81-117.

Hoffman, Stanley. “An American Social Science: International Relations.” Daedalus 106, no. 3 (1977): 41-60.

Horowitz, Richard. "International Law and State Transformation in China, Siam, and the Ottoman Empire during Nineteenth century." Journal of World History 15, no. 4 (2005): 445-86.

Huntington, Samuel. The Clash of Civilizations and the Remaking of World Order. New York: Simon and Scuster, 
1996.

Inoguchi, Takashi. “Are There any Theories of International Relations in Japan.” International Relations of the Asia Pacific 7, no. 3 (2007): 369-90.

Kahler, Miles. "International Relations: Still an American Science?" In Ideas and Ideals: Essays on Politics in Honor of Stanley Hoffmann, edited by L Miller and MH Smith, 395-414. Boulder, CO: Westview, 1993.

Kang, David C. "Hierarchy and Legitimacy in International Systems: The Tribute System in Early Modern East Asia.” Security Studies 19, no. 4 (2010): 591-622.

Kidron, Carol A. "Surviving a Distant Past: A Case Study of the Cultural Construction of Trauma Descendant Identity." Ethos 3, no. 4 (2004): 513-44.

Klebleyev, Aziz. "Islamic Legacy beyond Islam: The Case of Uzbekistan.” Administrative Culture 15, no. 2 (2014): 143-56.

Layne, Christopher. "The Unipolar Illusion Revisited: The Coming End of the United States' Unipolar Moment." International Security 31, no. 2 (2006): 7-41.

Makarychev, Andrey, and Morozov Viatcheslav. "Is 'Non-Western Theory' Possible? The Idea of Multipolarity and the Trap of Epistemological Relativism in Russian IR.” International Studies Review 15, no. 3 (2013): 328-50.

Onar, Nora Fisher. "Historical Legacies in Rising Powers: Toward a (Eur)Asian Approach." Critical Asian Studies 45, no. 3 (2013): 411-30.

Phillips, Andrew. "Civilising Missions and the Rise of International Hierarchies in Early Modern Asia." Millennium: Journal of International Studies 42, no. 3 (2014): 714.

Qin, Yaqing. "Relationality and Processual Construction: Bringing Chinese Ideas into International Relations Theory." Social Sciences in China 30, no. 3 (2009): 5-20.

"Why is there no Chinese IRT?" International Relations of the Asia Pacific 7, no. 2 (2007): 313-40.

Savage, Jesse Dillon. "The Stability and Breakdown of Empire: European Informal Empire in China, Ottoman Empire and Egypt." European Journal of International Relations 17, no. 2 (2010): 161-85.

Shahi, Deepshikha, and Gennaro Ascione. "Rethinking the Absence of Post-Western International Relations Theory in India: 'Advaitic monism' as an Alternative Epistemological Resource.” European Journal of International Relations 22, no. 2 (2016): 313-34.

Smith, Steve. "The United States and the Discipline of International Relations: 'Hegemonic Country, Hegemonic Discipline'.” International Studies Review 4, no. 2 (2002): 67-85.

Tickner, Ann J. “A Critique of Morgenthau's Principles of Political Realism.” In International Politics: Enduring Concepts and Contemporary Issues, edited by Robert J. Art and Robert Jervis, 15-27. New York: Pearson, Longman, 2005.

Tickner, Ann J., and Andrei P. Tsygankov. "Responsible Scholarship in International Relations: A Symposium." International Studies Review 10, no. 4 (2008): 661-66

Tickner, Arlene B. "Latin American IR and the Primacy of lo práctico." International Studies Review 10, no. 4 (2008): 735-48.

Tickner, Arlene B. "Seeing IR Differently: Notes from the Third World." Millennium: Journal of International Studies 32, no. 2 (2003): 295-324.

Tickner, Arlene, and Ole Wæver. "Conclusion: Worlding Where the West Once Was." In International Relations Scholarship around the World, edited by Arlene Tickner and Ole Wæver, 328-42. London and New York: Routledge, 2009.

- International Relations Scholarship around the World: Worlding beyond the West. New York: Routledge, 2009.

Tingyang, Zhao. "Rethinking Empire from a Chinese Concept 'All-under-Heaven' (Tian-xia).” Social Identities 12, no. 1 (2006): 29-41.

Tsygankov, Andrei P. “The Irony of Western Ideas in a Multicultural World: Russians' Intellectual Engagement with the 'End of History' and 'Clash of Civilizations'.” International Studies Review 5, no. 1 (2003): 53-76. 
"Self and Other in International Relations Theory: Learning from Russian Civilizational Debates." International Studies Review 10, no. 4 (2008): 762-75.

Tsygankov, Andrei, and Pavel Tsygankov. "National Ideology and IR Theory: Three Incarnations of the 'Russian Idea'.” European Journal of International Relations 16, no. 4 (2010): 663-86.

Wæver, Ole. "The Sociology of not so International Discipline: American and European Developments in International Relations." International Organisation 52, no. 4 (1998): 687-727.

Wight, Martin. International Theory: The Three Traditions, edited by Gabriele Wight and Brien Porter. Leicester and London: Leicester, 1991.

Zhang, Feng. "Rethinking the 'Tribute System': Broadening the Conceptual Horizon of Historical East Asian Politics.” Chinese Journal of International Politics 2, no. 4 (2009): 545-74.

Zhang, Yongjin, and Barry Buzan. "The Tributary System as International Society in Theory and Practice." Chinese Journal of International Politics 5, no. 1 (2012): 3-36. 